\title{
Quantitative microbial risk assessment for Staphylococcus aureus in natural and processed cheese in Korea
}

\author{
Heeyoung Lee, ${ }^{*}$ Kyunga Kim, $†$ Kyoung-Hee Choi, $\ddagger^{1}$ and Yohan Yoon*1 \\ *Department of Food and Nutrition, Sookmyung Women's University, Seoul 140-742, Korea \\ †Biostatistics and Clinical Epidemiology Center, Samsung Medical Center, Seoul 135-710, Korea \\ ‡Department of Oral Microbiology, College of Dentistry, Wonkwang University, Iksan, Jeonbuk 570-749, Korea
}

\section{ABSTRACT}

This study quantitatively assessed the microbial risk of Staphylococcus aureus in cheese in Korea. The quantitative microbial risk assessment was carried out for natural and processed cheese from factory to consumption. Hazards for $S$. aureus in cheese were identified through the literature. For exposure assessment, the levels of $S$. aureus contamination in cheeses were evaluated, and the growth of $S$. aureus was predicted by predictive models at the surveyed temperatures, and at the time of cheese processing and distribution. For hazard characterization, a dose-response model for $S$. aureus was found, and the model was used to estimate the risk of illness. With these data, simulation models were prepared with @RISK (Palisade Corp., Ithaca, $\mathrm{NY}$ ) to estimate the risk of illness per person per day in risk characterization. Staphylococcus aureus cell counts on cheese samples from factories and markets were below detection limits $(0.30-0.45 \mathrm{log} \mathrm{cfu} / \mathrm{g})$, and pert distribution showed that the mean temperature at markets was $6.63^{\circ} \mathrm{C}$. Exponential model $[P=1-\exp (7.64$ $\left.\times 10^{-8} \times N\right)$, where $N=$ dose] for dose-response was deemed appropriate for hazard characterization. Mean temperature of home storage was $4.02^{\circ} \mathrm{C}$ (log-logistic distribution). The results of risk characterization for $S$. aureus in natural and processed cheese showed that the mean values for the probability of illness per person per day were higher in processed cheese (mean: $2.24 \times 10^{-9}$; maximum: $7.97 \times 10^{-6}$ ) than in natural cheese (mean: $7.84 \times 10^{-10}$; maximum: $2.32 \times 10^{-6}$ ). These results indicate that the risk of $S$. aureus-related foodborne illness due to cheese consumption can be considered low under the present conditions in Korea. In addition, the developed stochastic risk assessment model in this study can be useful in establishing microbial criteria for $S$. aureus in cheese.

\footnotetext{
Received March 23, 2015.

Accepted April 24, 2015.

${ }^{1}$ Corresponding authors: kheechoi@wonkwang.ac.kr and yyoon@ sookmyung.ac.kr
}

Key words: microbial risk assessment, Staphylococcus aureus, cheese, exposure assessment, risk characterization

\section{INTRODUCTION}

Microbial risk assessment is a part of microbial risk analysis, which is composed of risk assessment, risk management, and risk communication ( $\mathrm{FAO} / \mathrm{WHO}$, 1997). It is a valuable assessment tool for understanding the risks posed by microorganisms and the prevention of foodborne illness. By conducting microbial risk assessment, the probability of experiencing illness due to pathogenic and environmental factors, influencing microbial growth, can be assessed (EPA, 2012). This assessment consists of hazard identification, exposure assessment, hazard characterization, and risk characterization (Codex Alimentarius Commission, 1999). Hazard identification is the identification of biological, chemical, and physical agents that may cause adverse health effects, and may be present in a particular food or group of foods. Exposure assessment is the qualitative or quantitative evaluation of the likely intake of biological, chemical, and physical agents via food. Hazard characterization refers to the qualitative or quantitative evaluation of the adverse health effects associated with the hazard, whereas risk characterization is the process of determining the qualitative or quantitative estimation, including attendant uncertainties, of the probability of occurrence of known or potential adverse health effects, as well as severity, in a given population based on hazard identification, hazard characterization, and exposure assessment (Codex Alimentarius Commission, 1999).

In 1997, the United States emphasized the importance of quantitative microbial risk assessment for achieving food safety objectives at the National Food Safety Initiative (Washington, DC). In addition, the interagency risk assessment consortium was established for food safety management, and the development of predictive models and other quantitative risk assessment tools has also been promoted (NFSI, 1997). The European Union 
has developed quantitative risk assessment methods at scientific steering committees, whereas Canada manages a decision-making framework and risk analysis framework at the Canadian Food Inspection Agency (Ottawa, ON, Canada). Besides these examples, Australia, Japan, and Korea employ the quantitative risk assessment tool of the Codex Alimentarius Commission.

Staphylococcus aureus is one of major pathogens related to outbreaks of foodborne illness, and this pathogen has been the cause of 171 outbreaks of foodborne illness in the past decade in Korea (MFDS, 2014b). Staphylococcus aureus has been isolated from various foods, especially meat and chicken (Jablonski and Bohach, 2001; Tamarapu et al., 2001; Jørgensen et al., 2005; Colombari et al., 2007). The Centers for Disease Control and Prevention (Atlanta, GA) reported 32 cheese-related foodborne outbreaks between 1973 and 1992, 11 of which may have been caused by raw milk cheese (Altekruse et al., 1998). In addition, S. aureus was isolated from cheese on sale in California in 2010 (FDA, 2010).

Many countries have quantitative microbial criteria for $S$. aureus in various foods, especially cheese; however, Korea applies a "zero tolerance" policy for $S$. aureus in cheese (MFDS, 2014c). Hence, the $S$. aureus risk in cheese in Korea needs to be evaluated. Accordingly, the objective of this study was to conduct a microbial risk assessment for $S$. aureus in natural and processed cheese in Korea.

\section{MATERIALS AND METHODS}

\section{Hazard Identification}

Staphylococcus aureus is a gram-positive, facultative anaerobic foodborne pathogen that is capable of growth from $7^{\circ} \mathrm{C}$ to $48.5^{\circ} \mathrm{C}, \mathrm{pH} 4.2$ to 9.3 , and $\mathrm{NaCl}$ concentrations of 0 to $15 \%$ (Bergdoll, 1989; Le Loir et al., 2003; Schmitt et al., 1990). Because of the wide ranges of these extrinsic factors, $S$. aureus is readily isolated from a variety of foods, such as milk and dairy products, meat, and chicken (Jablonski and Bohach, 2001; Tamarapu et al., 2001; Jørgensen et al., 2005; Colombari et al., 2007). Staphylococcus aureus was first identified in 1880 in Aberdeen, United Kingdom, and the first recorded food-related $S$. aureus outbreak was due to Cheddar cheese in 1884 (Anonymous, 1984). Although foodborne illness related to cheese has not yet occurred in Korea, occasional occurrence has been observed in countries that have high annual consumption of cheese, such as the United States and European countries, especially related to consumption of natural cheeses (Barrett, 1986; FDA, 2010; NPR, 2010). There- fore, acceptable limits and microbial criteria for contamination of cheese by $S$. aureus have been established in many countries.

In Korea, the criteria for cheese were divided into those for natural cheese and those for processed cheese. Natural cheese is defined as that manufactured by removing the whey after coagulation of raw milk or milk product through addition of lactic acid bacteria, protein curd enzymes, and organic acid, whereas processed cheese refers to that containing more than $50 \%$ milk solids derived from natural cheese (MFDS, 2014c). After hazard identification of S. aureus in cheese, quantitative microbial risk assessment was performed in natural and processed cheese, as presented in Figure 1.

\section{Exposure Assessment}

Prevalence. To evaluate the prevalence and contamination levels of $S$. aureus, natural and processed cheese samples were collected from 2 cheese factories in Korea, and analyzed during summer and winter to allow comparison of the effects of season. For natural cheese (Brie and Camembert), the following samples were collected for analysis: raw milk, pasteurized milk, cheese before ripening, cheese after packaging, and cheese before shipping. For processed cheese (Cheddar slices, Mozzarella slices, and Gouda slices), the following samples were collected: cheese base, cheese after packaging, and cheese before shipping. Upon collection, the samples were placed in a cooler and quickly transported to our laboratory for evaluation of the prevalence and contamination levels of $S$. aureus. The milk samples were plated on tryptic soy agar (TSA; Becton, Dickinson and Co., Sparks, MD) and mannitol salt agar (MSA; Becton, Dickinson and Co.) for enumeration of total bacteria and $S$. aureus cell counts, respectively. The cheese samples (25 g or 1 slice) were aseptically transferred into a sample bag (3M, St. Paul, MN), and $50 \mathrm{~mL}$ of $0.1 \%$ buffered peptone water (Becton, Dickinson and Co.) was added, after which the samples were pummeled for $120 \mathrm{~s}$ (BagMixer, Interscience, St. Nom, France). Aliquots of $1 \mathrm{~mL}$ of the homogenates were then plated on TSA and MSA. To evaluate contamination levels at the markets, natural cheese (Brie, Camembert, and Mozzarella cheese) and processed cheese (Cheddar slices, Gouda slices, and Mozzarella slices) samples were collected from markets during the summer and winter for analysis. Natural cheese (25 g) and processed cheese (1 slice) were also analyzed according to the methods described above. The colonies were counted manually after incubation at $35^{\circ} \mathrm{C}$ for $24 \mathrm{~h}$. Presumptive colonies of $S$. aureus were further analyzed by $16 \mathrm{~s}$ rDNA analysis for confirmation of $S$. 


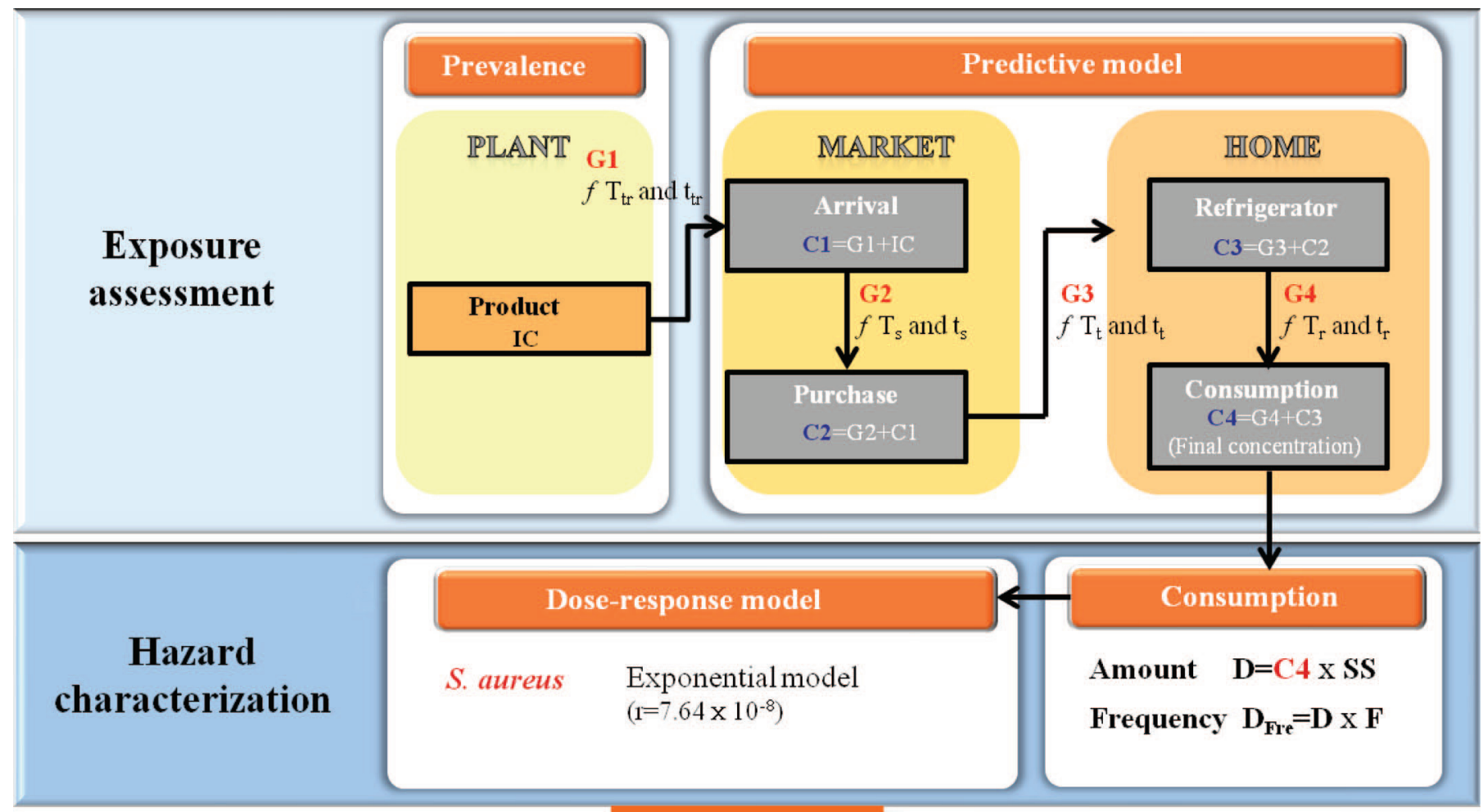

Using @ RISK program

\section{\begin{tabular}{c|c} 
Risk & Probability of illness per person per day \\
characterization
\end{tabular}}

Figure 1. Flow diagram of quantitative microbial risk assessment of Staphylococcus aureus in natural and processed cheeses. IC $=$ initial concentration; $\mathrm{C}_{i}=$ concentration of $S$. aureus in cheese at that point; $\mathrm{G}_{i}=$ growth of $S$. aureus in cheese at that point; $f=$ function of; $\mathrm{T}_{\mathrm{tr}}=$ temperature during transport to market; $\mathrm{t}_{\mathrm{tr}}=$ time for transportation to market; $\mathrm{T}_{\mathrm{s}}=$ temperature of storage/display; $\mathrm{t}_{\mathrm{s}}=$ time of storage/ display; $\mathrm{T}_{\mathrm{t}}=$ temperature during transportation to consumer homes; $\mathrm{t}_{\mathrm{t}}=$ time for transportation to consumer's home; $\mathrm{T}_{\mathrm{r}}=$ temperature held at home refrigerators; $\mathrm{t}_{\mathrm{r}}=$ time held at home refrigerators; $\mathrm{SS}=$ serving size; $\mathrm{D}=$ dose per serving; $\mathrm{F}=$ consumption frequency; $\mathrm{D}_{\text {Fre }}=$ dose per day. Color version available online.

aureus with primers of $27 \mathrm{~F}$ ( $5^{\prime}$-AGA GTT TGA TCM TGG CTC AG-3') and 1492R (5'-TAC GGY TAC CTT GTT ACG ACT T-3'). The PCR mixture (30 $\mu \mathrm{L}$ ) was formulated with $3 \mu \mathrm{L}$ of $10 \times$ reaction buffer, $1 \mu \mathrm{L}$ of $10 \mathrm{~m} M$ deoxynucleotide triphosphates, $1 \mu \mathrm{L}$ of $5 \times$ Band Doctor (Applied Biosystems, Foster City, $\mathrm{CA}), 1 \mu \mathrm{L}$ of each $10 \mathrm{p} M$ primer, $1 \mu \mathrm{L}$ of template DNA, $21.5 \mu \mathrm{L}$ of sterilized distilled water, and $0.2 \mu \mathrm{L}$ of 2.5 U EF-Taq polymerase (Solgent, Daejeon, Korea). Activation of Taq polymerase was carried out at $95^{\circ} \mathrm{C}$ for $2 \mathrm{~min}$, followed by 35 cycles of $95^{\circ} \mathrm{C}, 55^{\circ} \mathrm{C}$, and $72^{\circ} \mathrm{C}$ for $1 \mathrm{~min}$ each, finishing with a 10 -min step at $72^{\circ} \mathrm{C}$. A multiscreen filter plate (Millipore Corp., Bedford, MA) was used for purification of the amplified samples, after which the sequencing reaction was conducted by a Prism BigDye Terminator v3.1 Cycle sequencing Kit (Applied Biosystems). The DNA samples containing the extension products were placed in $\mathrm{Hi}$-Di formamide (Applied Biosystems). The mixture was then exposed to $95^{\circ} \mathrm{C}$ for $5 \mathrm{~min}$, followed by $5 \mathrm{~min}$ on ice, and then analyzed by using a DNA analyzer (ABI Prism 3730XL DNA analyzer, Applied Biosystems).

Initial Contamination Level. Appropriate data distributions were identified through a literature search, and the collected prevalence data on $S$. aureus were fitted to $\beta$-distribution $\left(\alpha_{1}=\right.$ the number of positive samples $+1, \alpha_{2}=$ tested total samples - positive samples +1$)$. Contamination levels for the final product at cheese factories were fitted to a uniform distribution ( $\mathrm{a}=$ minimum contamination level, $\mathrm{b}=$ maximum contamination level), because uniform distribution can be defended as being the maximally noncommittal distribution for an estimate of probability given that no information is available about the probability (Vose, 
1998). Ultimately, the initial concentrations ( $\log \mathrm{cfu} / \mathrm{g})$ of $S$. aureus on natural and processed cheese were calculated by prevalence $\times$ contamination level.

Contamination Levels at Consumption. To predict $S$. aureus growth patterns during storage and transportation of the cheese, the mathematical models developed by the MFDS (2013) were used for both natural and processed cheese, with consideration of the worst-case scenario. Among those examined, Brie cheese (natural) and Mozzarella slices (processed) displayed the highest maximum specific growth rate $\left(\boldsymbol{\mu}_{\max }\right)$. The equations were as follows:

$$
\begin{gathered}
\text { Brie cheese: } \sqrt{\mu_{\max }}=0.0268 \times(T-5.2687), \\
\lambda=18864.1 \times e^{-0.6432 T}, \\
\text { Mozzarella slices: } \sqrt{\mu_{\max }}=0.0265 \times(T-6.3547), \\
\lambda=4946.4 \times e^{-0.3085 T},
\end{gathered}
$$

where $T=$ temperature; and $\lambda=$ lag phase duration. The equations were used to calculate the kinetic parameters $\left(\mu_{\max }\right.$ and $\left.\lambda\right)$ to estimate the changes in $S$. aureus cell counts during storage and transportation.

Temperature Profile. Temperature information during transportation from the factory to the markets was collected by personal communication. Temperatures for cheese storage at the markets were measured using an infrared ray thermometer (HS33CT, Hansung, Seoul, Korea) every $30 \mathrm{~min}$ for 6 to $9 \mathrm{~h}$. Home refrigerators were monitored using a data logger (Testo 174H, Testo, Lenzkirch, Germany), and the storage temperatures of home refrigerators were measured every $10 \mathrm{~min}$ for 3 to $4 \mathrm{~d}$. These temperature data were fitted to the @RISK program, version 5.7 (Palisade Corp., Ithaca, NY), to obtain appropriate data distributions.

Cheese Consumption in Korea. Information on the amount of consumption and frequency data for natural and processed cheeses were cited from a study by the MFDS (2013) to estimate the risk of $S$. aureus exposure through consumption of natural and processed cheese in Korea.

\section{Dose-Response Model}

The probability of foodborne illness from the intake of $S$. aureus cells was estimated by the following doseresponse model, developed by Rose and Haas (1999):

$$
P=1-e^{r \times N},
$$

where $P$ is the probability of illness, $r$ is the probability of $S$. aureus single cells causing foodborne illness, and $N$ is the number of $S$. aureus cells ingested (cfu/serving).

\section{Risk Characterization}

To estimate the probability of experiencing $S$. aureus foodborne illness per person per day due to cheese consumption, simulation models were prepared with the exposure assessment data, including prevalence, contamination level, temperature distribution, amount and frequency of cheese consumption, and dose-response model, in the @RISK program (Palisade Corp.) with settings for 10,000 iterations of Latin Hypercube sampling (Tables 1 and 2).

\section{RESULTS AND DISCUSSION}

\section{Prevalence and Contamination Level of S. aureus}

For all cheese samples (90 natural cheese and 308 processed cheese samples), $S$. aureus was below the detection limit (natural cheese: $0.30 \mathrm{log} \mathrm{cfu} / \mathrm{g}$; processed cheese: $0.45 \log \mathrm{cfu} / \mathrm{g}$ ). Such low levels of $S$. aureus contamination may be due to the "zero-tolerance" policy of Korea. In contrast, the European Union has quantitative microbial criteria for $S$. aureus on soft cheese (n $=5, \mathrm{c}=2, \mathrm{~m}=100, \mathrm{M}=1,000$, where $\mathrm{n}=$ number of sample units to be chosen independently and randomly from the lot, $\mathrm{c}=$ maximum allowable number of sample units yielding results between $\mathrm{m}$ and $\mathrm{M}, \mathrm{m}=\mathrm{a}$ microbiological limit that separates good quality from marginally acceptable quality, and $\mathrm{M}=\mathrm{a}$ microbiological limit above which sampling results are unacceptable or defective) and fresh cheese $(\mathrm{n}=5, \mathrm{c}=2, \mathrm{~m}=100$, $M=100$ ), and Canada, Australia, New Zealand, and Hungary also have quantitative microbial criteria. This implies that the quantitative microbial criteria of $S$. aureus in cheese in Korea could be considered if the microbial risk of $S$. aureus in cheese is not increased. Thus, quantitative microbial risk assessment is needed for quantitative evaluation of the risk of $S$. aureus in cheese.

Because the $S$. aureus contamination was below the detection level in all samples, initial levels of $S$. aureus contamination were calculated with the $\beta$ distribution $\times$ uniform distribution. The $\beta$ distribution describes the probability $(P)$ of an event occurring, and is a result of applying Bayes' Theorem to the observed events. In our research, the prevalence data were fitted to $\beta$ distribution because of the lack of information about $P$ before the observed events (Vose, 1998). According to 
MICROBIAL RISK ASSESSMENT FOR STAPHYLOCOCCUS AUREUS IN KOREAN CHEESE

5935

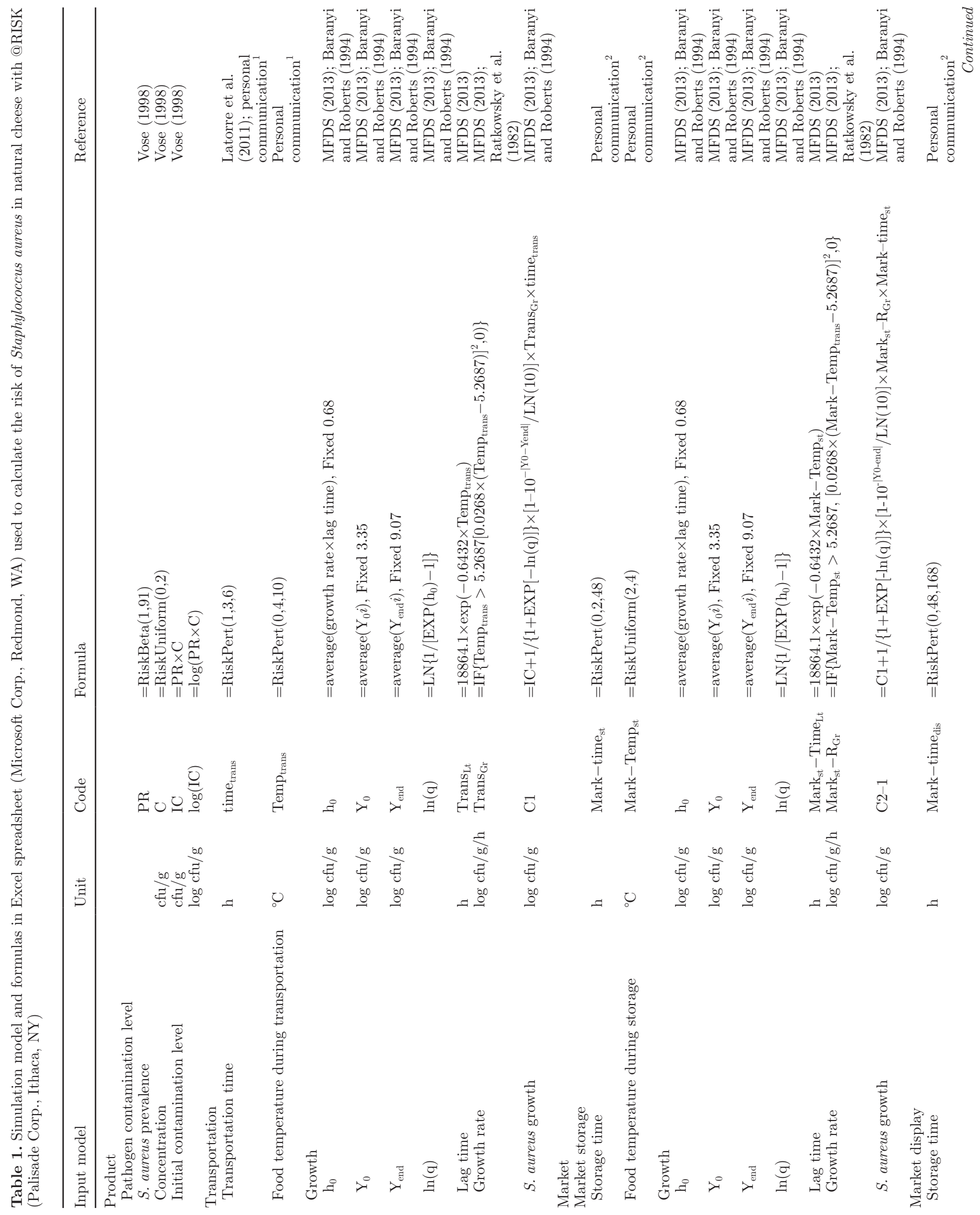




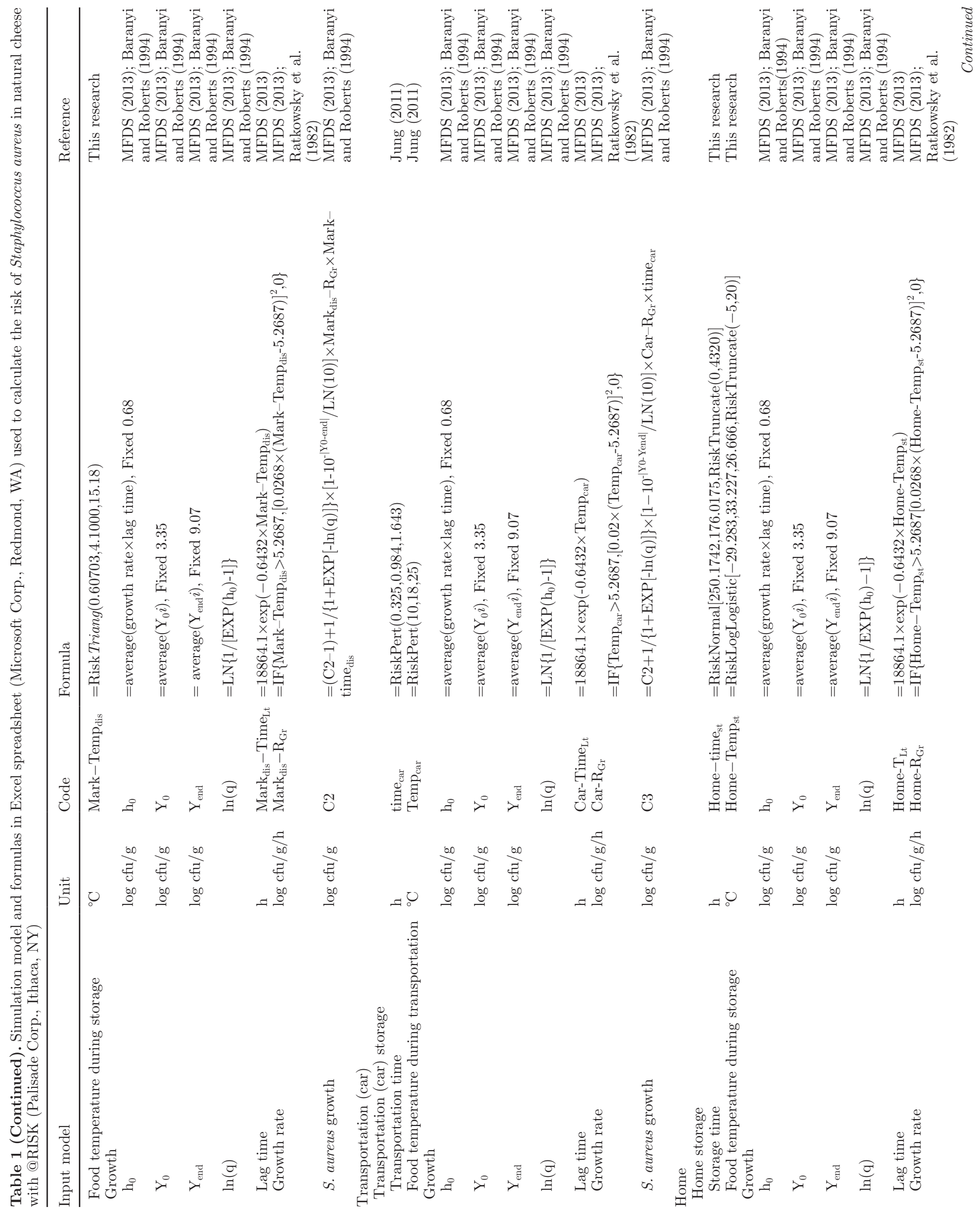


the distribution, the initial contamination levels of $S$. aureus in cheese were estimated to be -2.35 and -2.73 $\log \mathrm{cfu} / \mathrm{g}$ for natural and processed cheeses, respectively (Tables 1 and 2 and Figure 2).

\section{Growth of S. aureus}

Because we assumed that the initial concentration of $S$. aureus on cheese would increase during transportation and display, the $S$. aureus contamination levels at each step were predicted with the $\mu_{\max }$ and $\lambda$ values calculated by mathematical models, which are presented in Equations [1] to [4]. The predicted amounts of $S$. aureus in natural cheese at arrival at the market, after storage at the market, at the moment of purchase, at the time of home arrival, and at the time of consumption were $-2.34,-2.34,-2.25,-2.22$, and $-2.17 \log \mathrm{cfu} / \mathrm{g}$, respectively, whereas the values for processed cheese were $-2.73,-2.73,-2.65,-2.62$, and $-2.32 \log \mathrm{cfu} / \mathrm{g}$, respectively (data not shown). During transportation and display at markets, significant $S$. aureus growth on the natural and processed cheese samples was not observed, due to the well-managed cold chain system. However, if the cheeses were placed at maximum temperature at the market $\left(15.18^{\circ} \mathrm{C}\right)$, which was estimated from examination of the temperature distribution (triang distribution) at markets (Figure 3 ), the $\mu_{\max }$ values of natural and processed cheese would be 0.27 and 0.23 $\log \mathrm{cfu} / \mathrm{g}$ per hour, respectively, indicating that the $S$. aureus cell counts on the cheese would significantly increase under such conditions.

\section{Temperature}

Data on temperature during transportation were collected through personal communication with the supervisor of a cheese manufacturing plant; it was not necessary to collect many samples because the temperature variation was minimal. Thus, a pert distribution was used to obtain the temperature distribution during transportation, with minimum $\left(0^{\circ} \mathrm{C}\right)$, mean $\left(4^{\circ} \mathrm{C}\right)$, and maximum $\left(10^{\circ} \mathrm{C}\right)$ data, and the values were fitted to a pert distribution (minimum $=0^{\circ} \mathrm{C}$, mean $=4^{\circ} \mathrm{C}$, maximum $=10^{\circ} \mathrm{C}$ ) to be used for prediction of $S$. aureus growth on the natural and processed cheeses. At the markets, the observed temperature of the cheese ranged from $0.90^{\circ} \mathrm{C}$ to $14.30^{\circ} \mathrm{C}$, with a mean of $6.65^{\circ} \mathrm{C}$, and the appropriate data distribution was determined to be the triang distribution (Figure 3). This fitted triang distribution indicated that the minimum, mean, and maximum temperatures were $0.61^{\circ} \mathrm{C}, 6.63^{\circ} \mathrm{C}$, and $15.18^{\circ} \mathrm{C}$. In Korea, cold storage temperature is legally defined as $0^{\circ} \mathrm{C}$ to $10^{\circ} \mathrm{C}$ (MFDS, 2014a), thus temperatures above $10^{\circ} \mathrm{C}$, which were found in the collected temperature 
LEE ET AL.

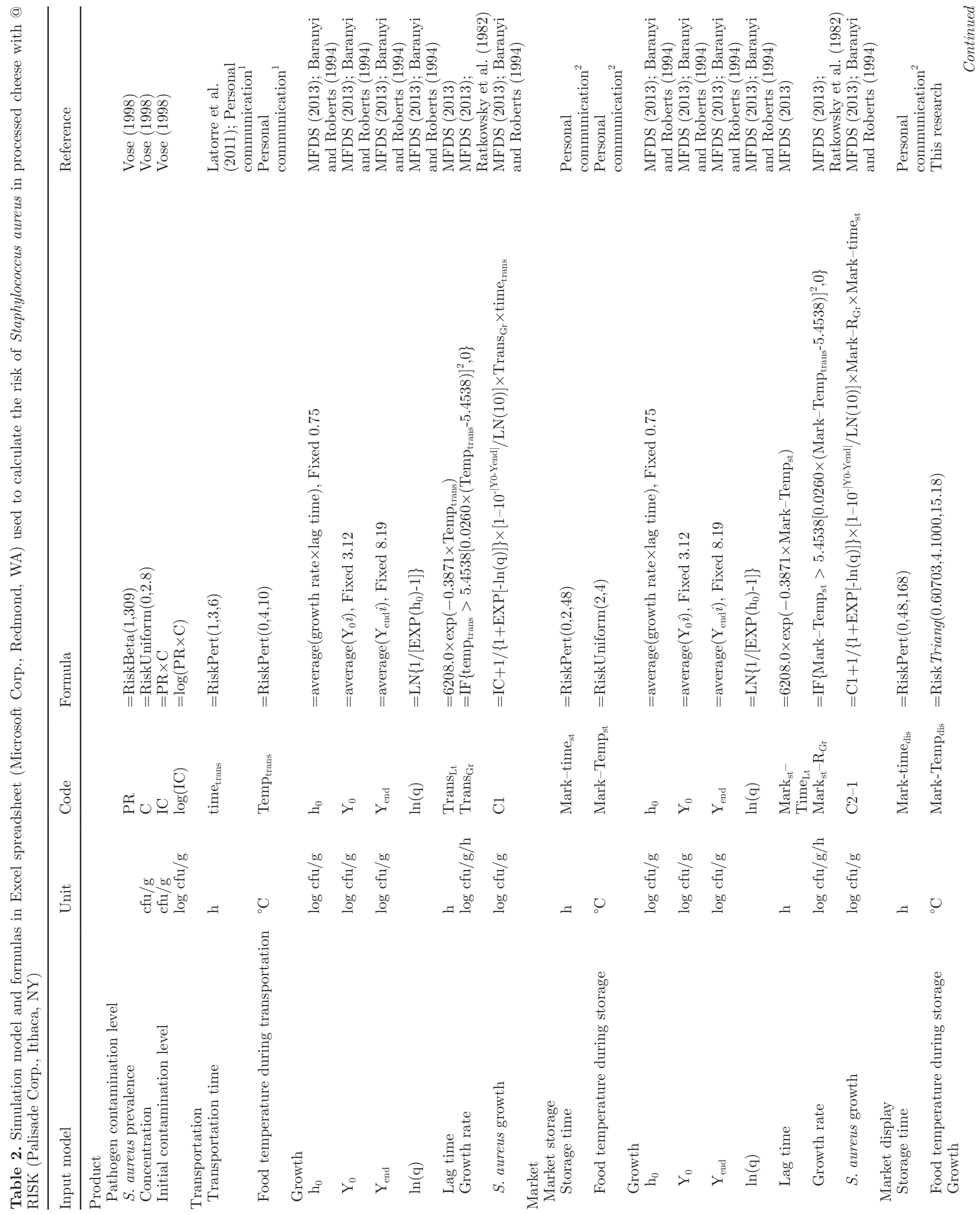


MICROBIAL RISK ASSESSMENT FOR STAPHYLOCOCCUS AUREUS IN KOREAN CHEESE

5939
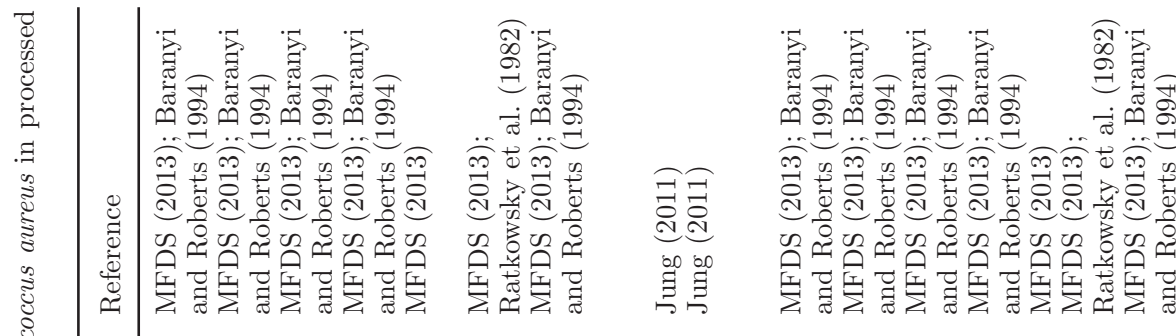

焉

n 0 舟

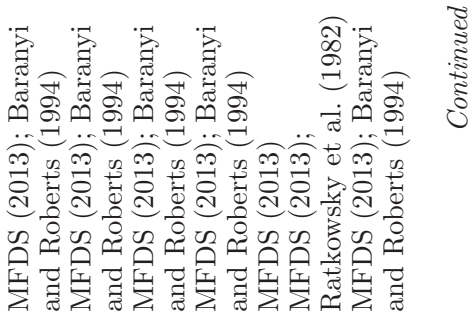

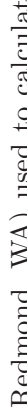

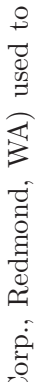

0

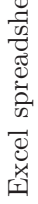

苛

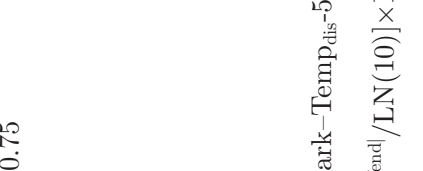

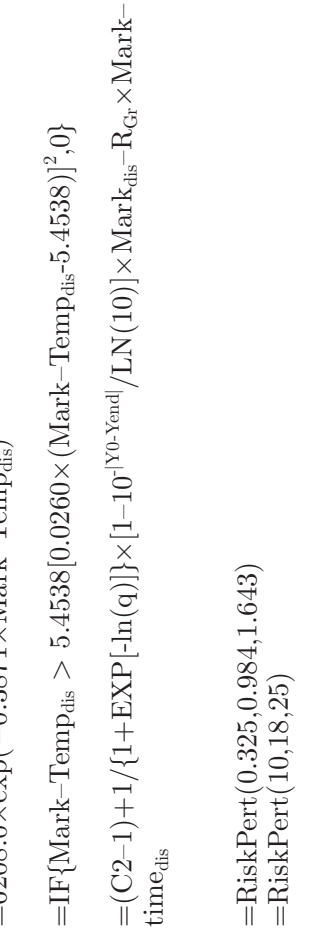

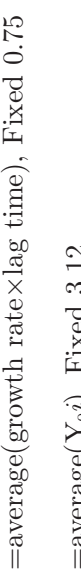

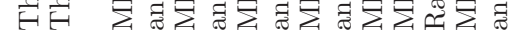

西

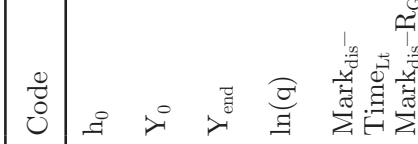

式
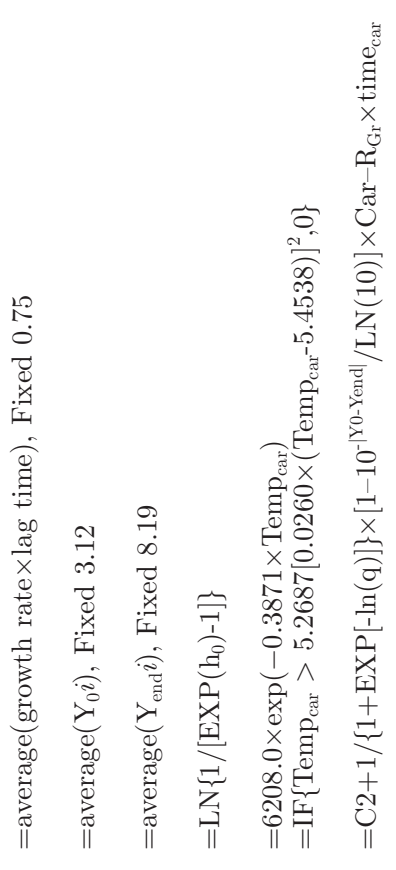

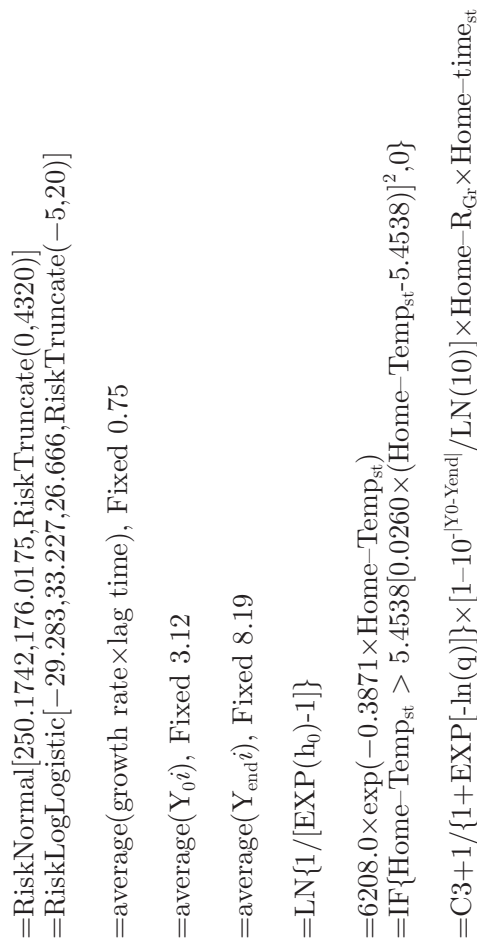

范

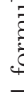

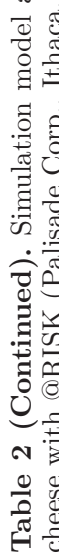

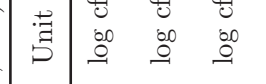

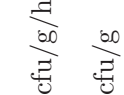

$\sqrt{1}$

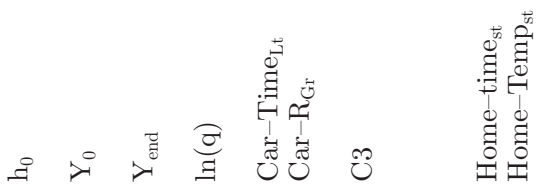

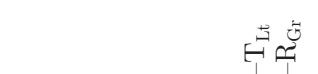

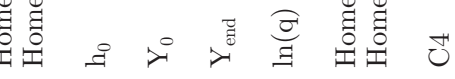

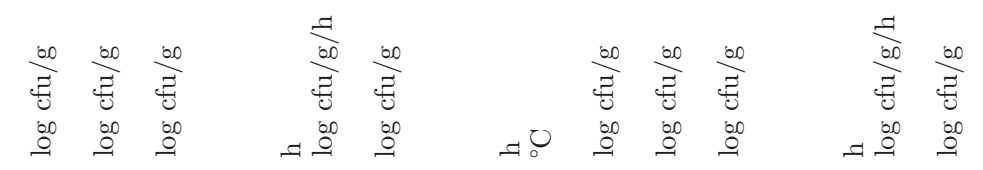

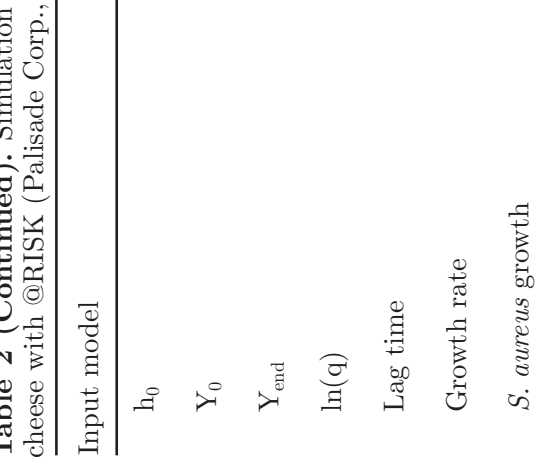

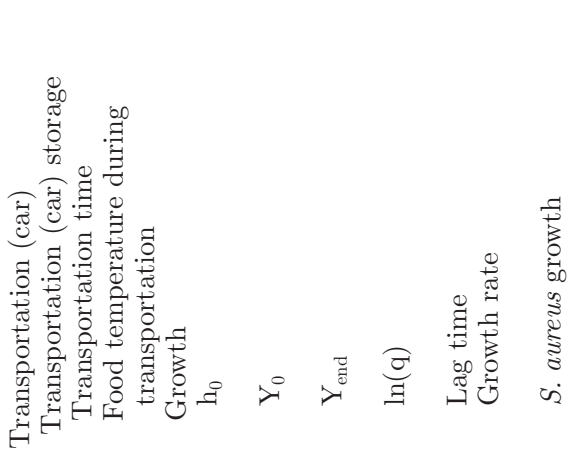

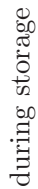

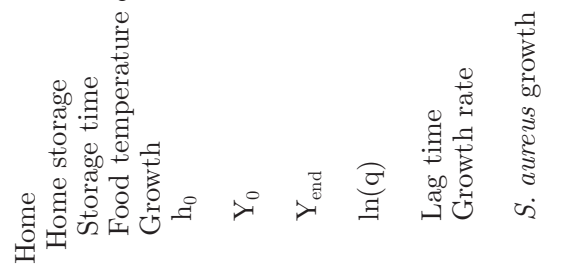

Journal of Dairy Science Vol. 98 No. 9, 2015 


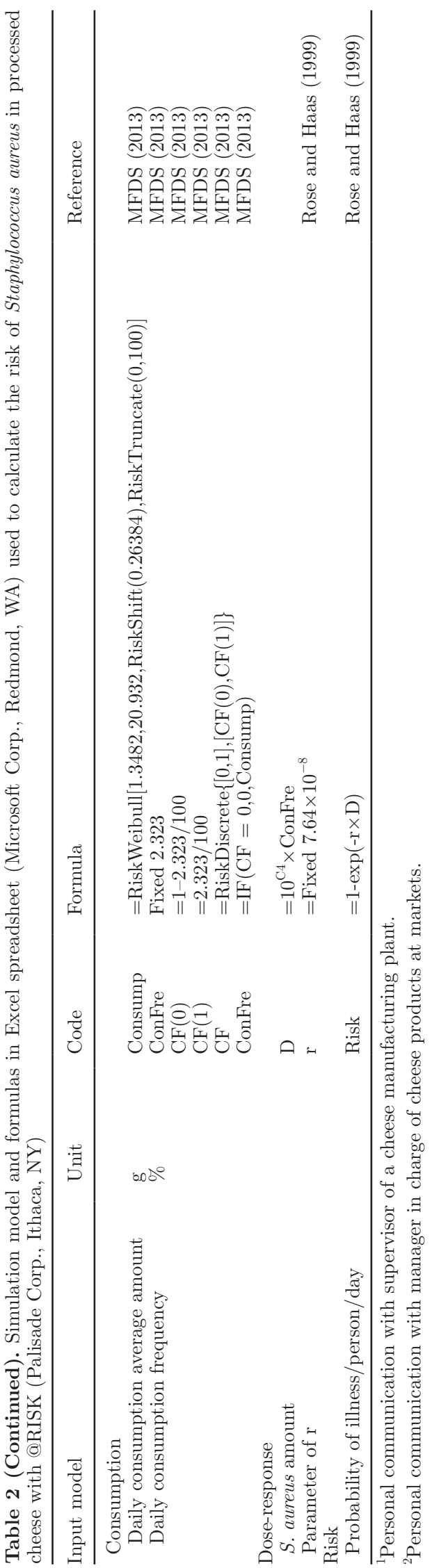

data, can be considered as temperature abuse. Hence, it is possible that $S$. aureus present on natural and processed cheese may occasionally be exposed to such abusive temperatures. However, the simulation for $S$. aureus growth with the observed temperature distribution did not show significant growth of the pathogen, because the 95th percentile for temperature at markets was $12.65^{\circ} \mathrm{C}$ (Figures 3 and 4 ). Lee et al. (2008) also surveyed the storage temperature of major chilled foods in refrigerators at markets in Korea, during which the mean temperature was determined to be $8.2^{\circ} \mathrm{C}$, showing a similar value to the results presented herein. In addition, Choi et al. (2011) also measured the surface temperatures of food in cold storage, finding it to range from $4.6^{\circ} \mathrm{C}$ to $10.6^{\circ} \mathrm{C}$, with a mean of $6.6^{\circ} \mathrm{C}$.

For home refrigerator temperatures, log-logistic distribution $(-26.084,30.149,24.258)$ was determined to have the best fit, and the minimum and maximum temperatures were determined to be -3.5 and $10.8^{\circ} \mathrm{C}$, respectively, with mean and standard deviation of $4.02^{\circ} \mathrm{C}$ and 2.27 (Figure 4). The study by Bahk (2010) also showed that log-logistic distribution was appropriate for home refrigerator temperatures, with $3.52^{\circ} \mathrm{C}$ as the mean temperature.

\section{Cheese Consumption in Korea}

According to the report by MFDS (2013), the mean value for natural cheese consumption was estimated to be $12.40 \pm 19.43 \mathrm{~g} / \mathrm{d}(95 \%$ CI: $0.915-34.90 \mathrm{~g} / \mathrm{d})$ with a frequency of 0.0389 , whereas the mean consumption of processed cheese was $19.46 \pm 14.39 \mathrm{~g} / \mathrm{d}$ (95\% CI: $2.6-40.0 \mathrm{~g} / \mathrm{d}$ ) with a frequency of 0.0232 .

\section{Dose-Response Model}

Rose and Haas (1999) suggested that the exponential model for the dose of $S$. aureus translated into likely occurrence of foodborne illness. The exponential model $\left[P=1-\exp \left(7.64 \times 10^{-8} \times N\right)\right]$ was used to calculate the risk of foodborne illness of $S$. aureus on natural and processed cheese.

\section{Risk Characterization}

To estimate the risk of foodborne illness due to $S$. aureus per serving of cheese with the simulation model, the values of input variables such as prevalence, temperature, and time of market storage, display at markets, home storage, amount of consumption, and intake frequency were randomly sampled from the appropriate distributions presented above for 10,000 iterations. The estimated probabilities of $S$. aureus-related foodborne illness per person per day were found to be $7.84 \times$ 


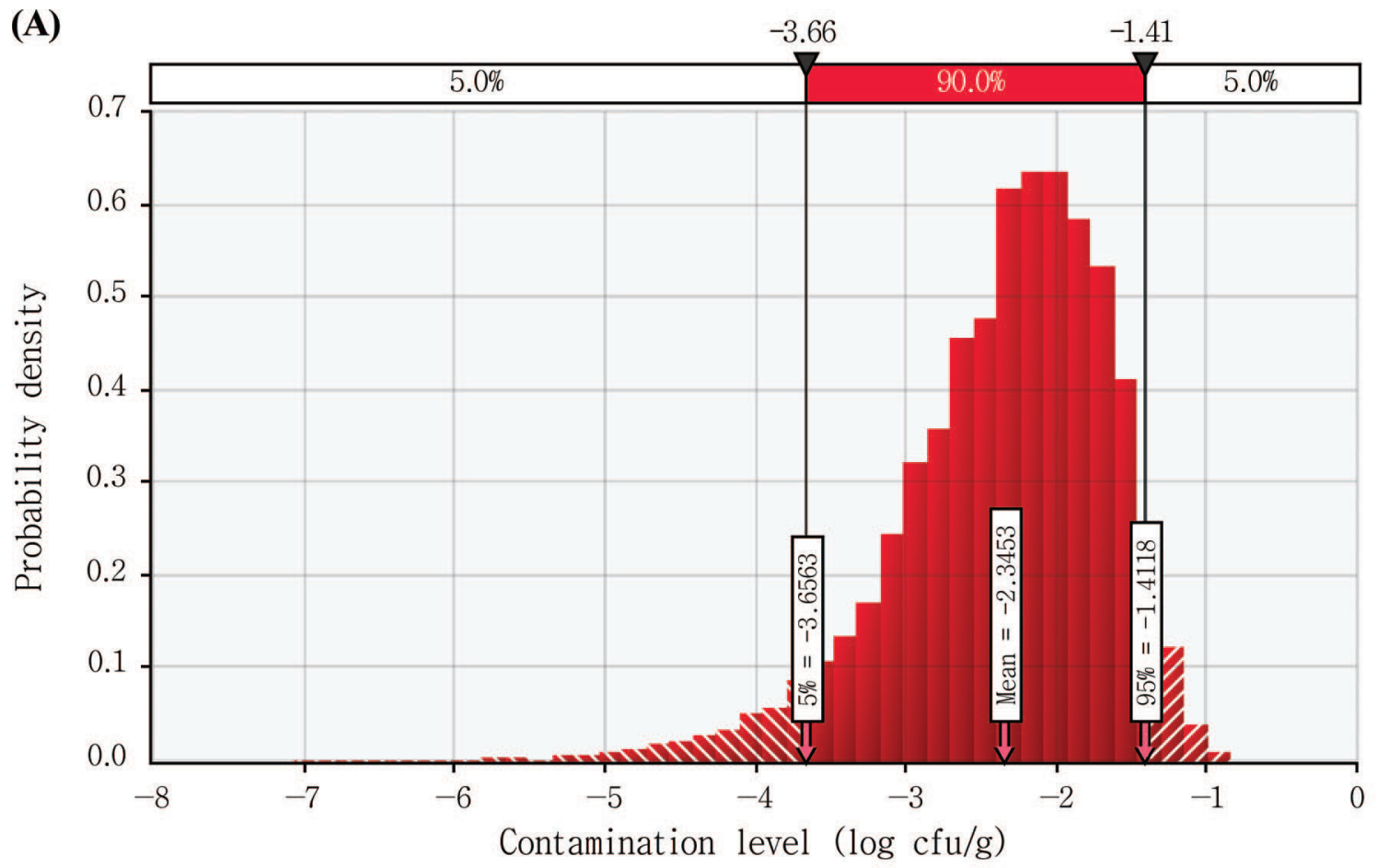

IC $(\log \mathrm{cfu} / \mathrm{g})$

Minimum $\quad-7.0664$

Maximum $\quad-0.8367$

Mean $\quad-2.3453$

Std Dev $\quad 0.7017$

Values $\quad 10000$

(B)

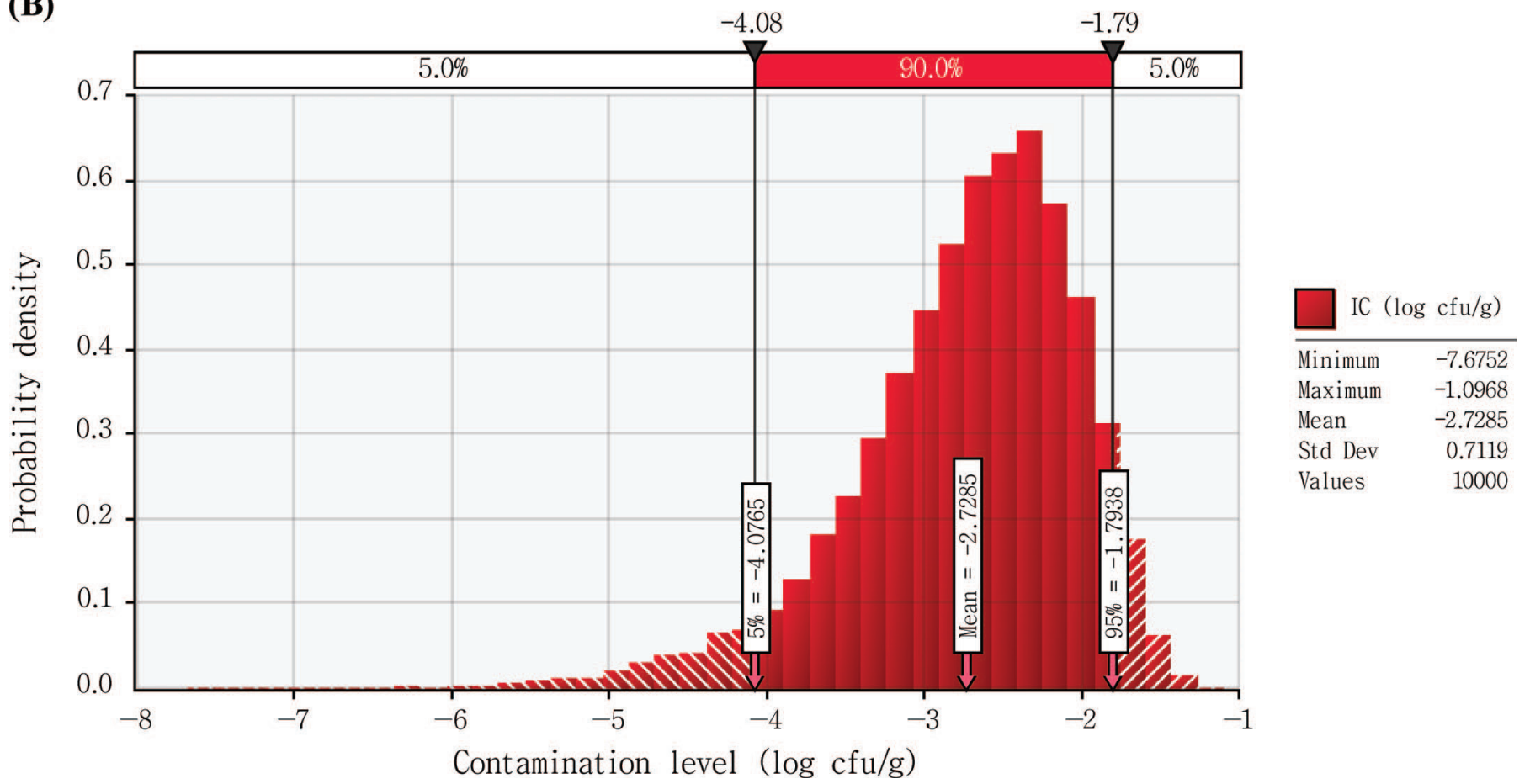

Figure 2. Probability density of simulated initial contamination (IC) level of Staphylococcus aureus in (A) natural and (B) processed cheese. Color version available online.

$10^{-10}$ and $2.24 \times 10^{-9}$ for natural and processed cheese, respectively, with low values of $1.22 \times 10^{-8}$ and 9.45 $\times 10^{-9}$, even for the 99 th percentile (Table 3 ). These results suggest that the probabilities of $S$. aureusrelated foodborne illness occurring per 1 million people per year are 0.286 and 0.818 for natural and processed 


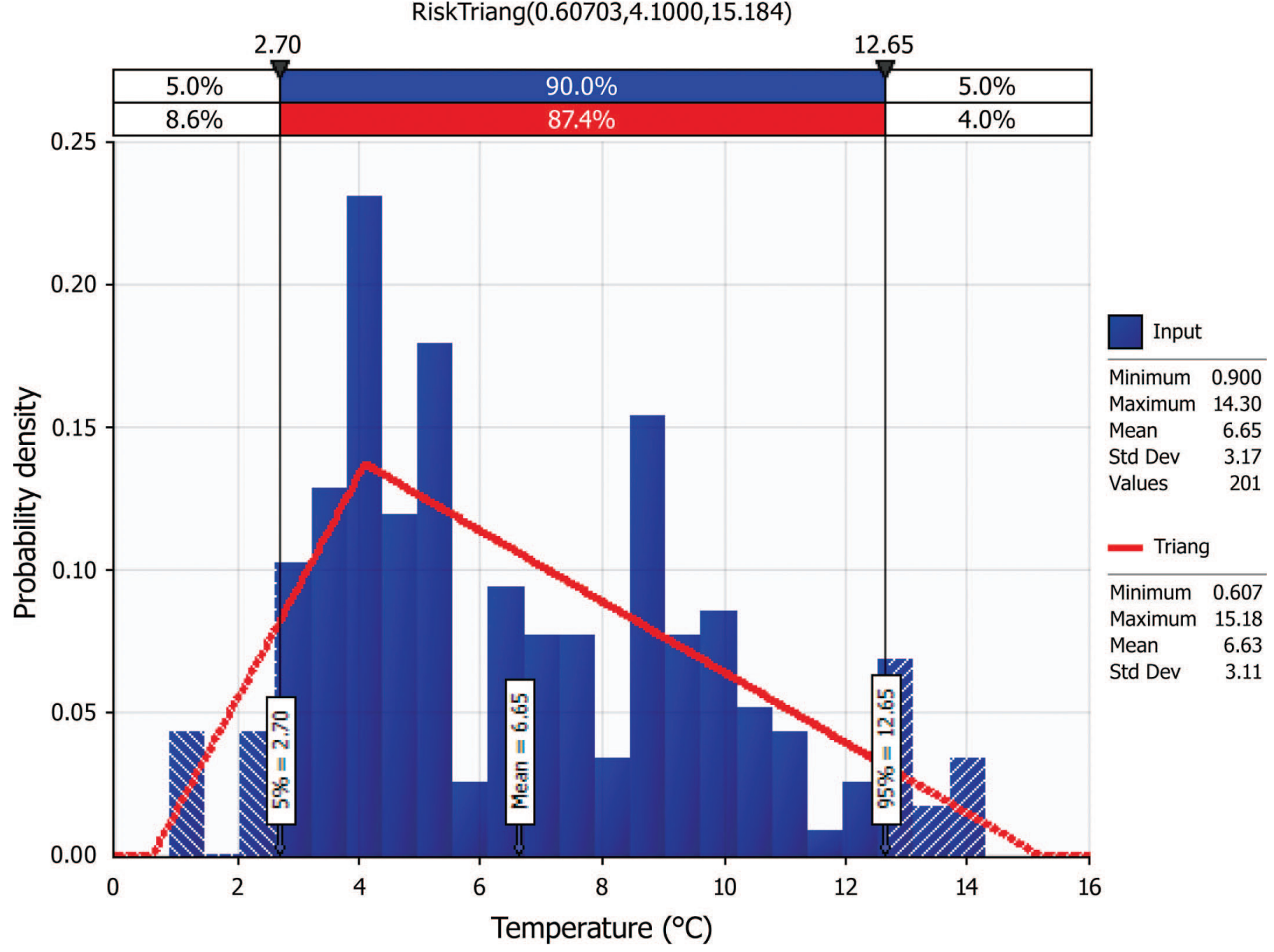

Figure 3. Temperature distribution at markets. Histogram is the graph of raw data and line is the best-fitted distribution (triang). Color version available online.

cheese, respectively. In a quantitative risk assessment of leafy green vegetables consumed at a salad bar, Franz et al. (2010) showed the mean probability of foodborne illness for Escherichia coli O157:H7, Salmonella, and Listeria monocytogenes to be $6.04 \times 10^{-6}, 6.83 \times 10^{-6}$, and $1.23 \times 10^{-8}$, respectively. In addition, the probabilities of listeriosis per person per day from eating lettuce at a restaurant or at home in Korea were 3.64 $\times 10^{-9}$ to $1.30 \times 10^{-7}$ and $4.71 \times 10^{-8}$ to $1.68 \times 10^{-6}$, respectively (Ding et al., 2013). Compared with these studies, the estimated risk of $S$. aureus on natural and processed cheeses determined herein can be considered as very low.

The low risk of $S$. aureus foodborne illness through cheese consumption may be caused by low initial levels of $S$. aureus, low consumption of cheese, low intake frequency, and low temperatures for product transpor- tation and storage in Korea. In Greece, the amount of cheese consumed annually per person is $32.57 \mathrm{~kg}(89.23$ $\mathrm{g} / \mathrm{d}$; Wisconsin Cheese, 2014), twice that in Korea. Thus, the comparatively low cheese consumption in Korea may result in a low risk of $S$. aureus in cheese.

Even though processed cheese had lesser growth of $S$. aureus compared with natural cheese, the annual risk estimate of processed cheese was higher, which was likely because of the higher consumption of this type of cheese. The regression coefficient values in Figure 5 show that the factors influencing $S$. aureus risk for natural and processed cheese in Korea were intake frequency and home storage temperature.

In conclusion, the risk of $S$. aureus-related foodborne illness through cheese consumption is low in Korea, and the developed stochastic risk assessment model in this study could be useful for quantitative risk assessment. 


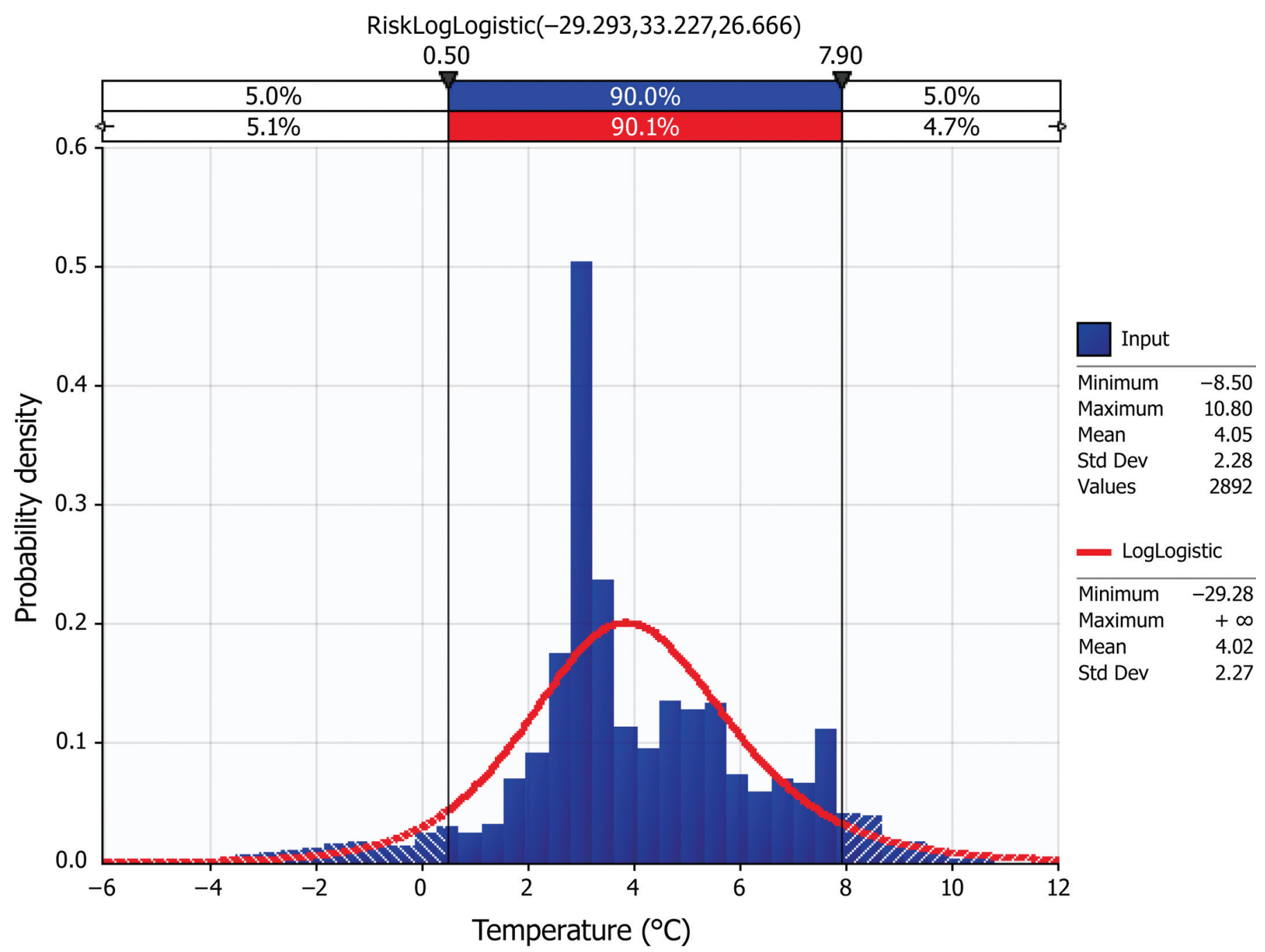

Figure 4. Temperature profile and distribution of home refrigerators. Histogram is the graph of raw data, and line is the best-fitted distribution (loglogistic). Color version available online.

Table 3. Probability of foodborne illness from Staphylococcus aureus per person per day due to the consumption of natural and processed cheeses

\begin{tabular}{|c|c|c|c|c|c|c|c|}
\hline \multirow[b]{2}{*}{ Cheese type } & \multicolumn{5}{|c|}{ Probability of illness/person per day } & \multirow[b]{2}{*}{ Maximum } & \multirow[b]{2}{*}{ Mean } \\
\hline & $5 \%$ & $25 \%$ & $50 \%$ & $95 \%$ & $99 \%$ & & \\
\hline Natural cheese & 0 & 0 & 0 & 0 & $1.22 \times 10^{-8}$ & $2.32 \times 10^{-6}$ & $7.84 \times 10^{-10}$ \\
\hline Processed cheese & 0 & 0 & 0 & 0 & $9.45 \times 10^{-9}$ & $7.97 \times 10^{-6}$ & $2.24 \times 10^{-9}$ \\
\hline
\end{tabular}


(A)

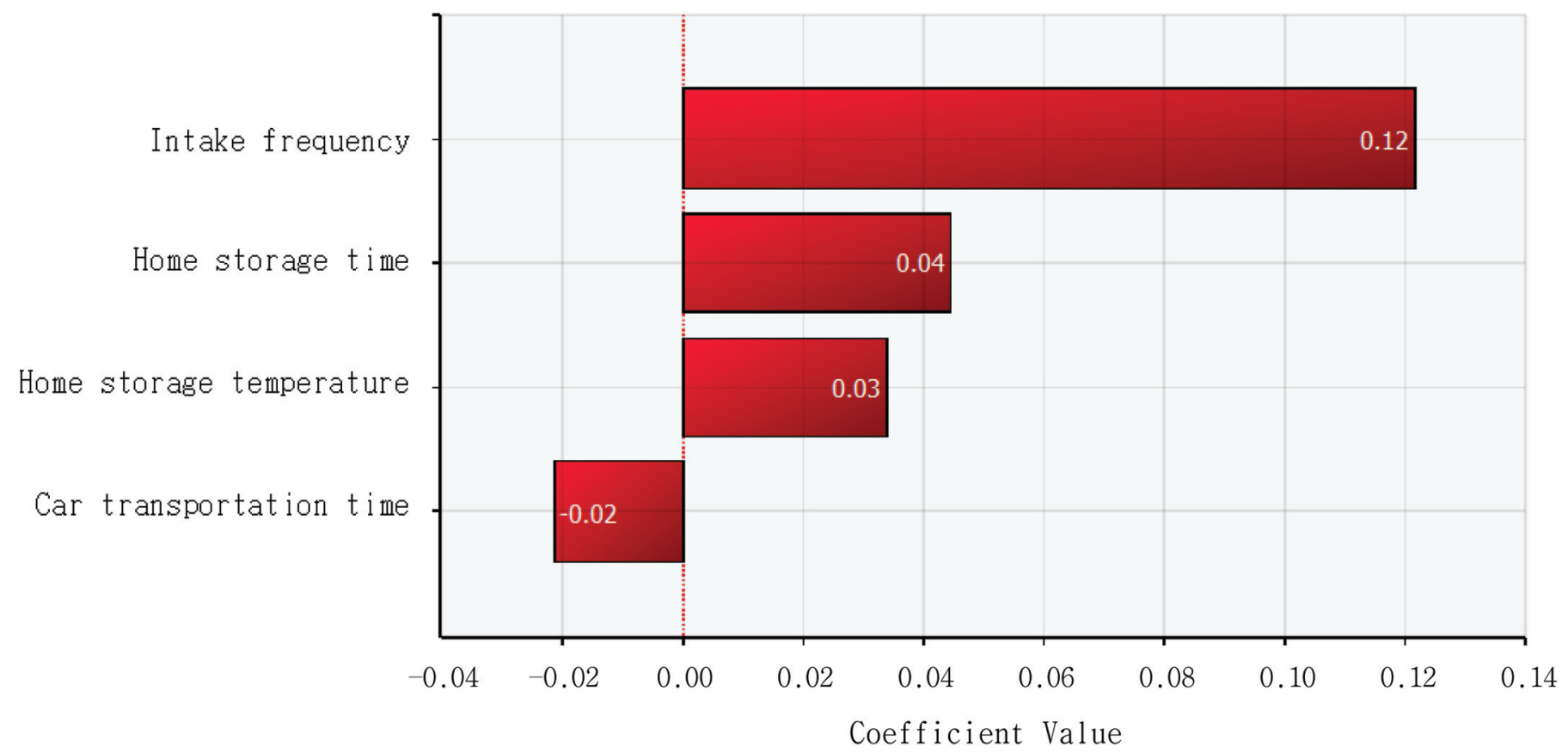

(B)

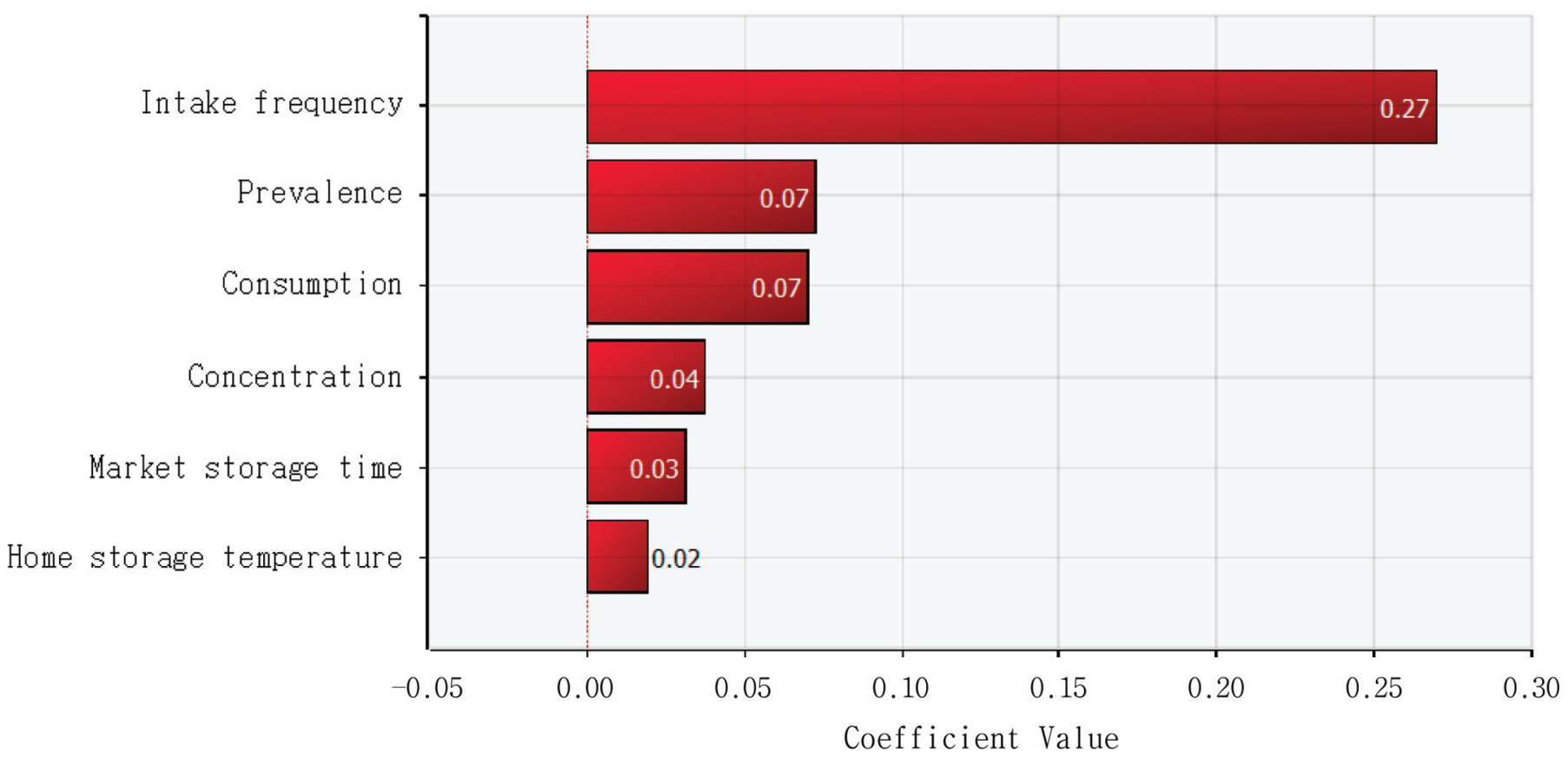

Figure 5. Regression coefficient values for sensitivity risk factors affecting probability of illness per person per day due to the consumption of natural cheese (A) and processed cheese (B). Color version available online. 


\section{ACKNOWLEDGMENTS}

This research was supported by a grant (13162MFDS927) from the Ministry of Food and Drug Safety (Cheongju, South Korea) in 2013.

\section{REFERENCES}

Altekruse, S. F., B. B. Timbo, J. C. Mowbray, N. H. Bean, and M. E. Potter. 1998. Cheese-associated outbreak of human illness in the United States, 1973 to 1992: Sanitary manufacturing practices protect consumers. J. Food Prot. 61:1405-1407.

Anonymous. 1984. On abscesses: Alexander Ogston (1844-1929). Rev. Infect. Dis. 6:122-128.

Bahk, G.-J. 2010. Statistical probability analysis of storage temperatures of domestic refrigerator as a risk factor of foodborne illness outbreak. Korean J. Food Sci. Technol. 42:373-376.

Baranyi, J., and T. A. Roberts. 1994. A dynamic approach to predicting bacterial growth in food. Int. J. Food Microbiol. 23:277-294.

Barrett, N. J. 1986. Communicable disease associated with milk and dairy products in England and Wales: 1983-1984. J. Infect. 12:265-272.

Bergdoll, M. S. 1989. Staphylococcus aureus. Pages 463-523 in Foodborne Bacterial Pathogens. M. P. Doyle, ed. Marcel Dekker Inc., New York, NY.

Choi, M.-S., J.-A. Choi, M. Kim, and G.-J. Bahk. 2011. The comparison and distribution of temperatures established in display stands and food surfaces for cold and frozen foods in large discount stores in Korea. J. Food Hyg. Safety 26:308-314.

Codex Alimentarius Commission. 1999. Principles and guidelines for the conduct of microbiological risk assessment. CAC/GL30. Accessed Dec. 28, 2014. http://www.fao.org/docs/eims/ upload/215254/CAC_GL30.pdf.

Colombari, V., M. D. Mayer, Z. M. Laicini, E. Mamizuka, B. D. Franco, M. T. Destro, and M. Landgraf. 2007. Foodborne outbreak caused by Staphylococcus aureus: Phenotypic and genotypic characterization of strains of food and human sources. J. Food Prot. 70:489-493.

Ding, T., J. Iwahori, F. Kasuga, J. Wang, F. Forghani, M.-S. Park, and D.-H. Oh. 2013. Risk assessment for Listeria monocytogenes on lettuce from farm to table in Korea. Food Contr. 30:190-199.

EPA (Environmental Protection Agency). 2012. EPA/100/J-12/001. Microbial risk assessment guideline: Pathogenic microorganisms with focus on food and water. Accessed Mar. 09, 2015. http:// nepis.epa.gov/Exe/ZyNET.exe/P100EQP4.TXT?ZyActionD=Zy Document $\&$ Client $=$ EPA $\&$ Index $=2011+$ Thru $+2015 \&$ Docs $=\& Q u e$ $\mathrm{ry}=\&$ Time $=\&$ EndTime $=\&$ SearchMethod $=1 \&$ TocRestrict $=\mathrm{n} \&$ To $\mathrm{c}=\&$ TocEntry $=\&$ QField $=\&$ QFieldYear $=\& Q$ FieldMonth $=\&$ QFiel $\mathrm{dDay}=\&$ IntQFieldOp $=0 \&$ ExtQFieldOp $=0 \&$ XmlQuery $=\&$ File $=\mathrm{D}$ $\% 3 \mathrm{~A} \% 5$ Czyfiles\%5CIndex\%20Data\%5C11thru $15 \% 5$ CTxt $\% 5$ C000 $00005 \% 5 \mathrm{CP} 100 \mathrm{EQP} 4$. txt $\&$ User $=$ ANONYMOUS\&Password $=$ ano nymous\&SortMethod $=\mathrm{h} \% 7 \mathrm{C}-\&$ MaximumDocuments $=1 \&$ FuzzyD egree $=0 \&$ ImageQuality $=$ r75 g8/r75g8/x150y150g16/i425\&Display $=\mathrm{p} \% 7 \mathrm{Cf} \&$ DefSeekPage $=\mathrm{x} \&$ SearchBack $=$ ZyActionL\&Back $=\mathrm{ZyAc}$ tionS\&BackDesc $=$ Results\%20page\&MaximumPages =1\&ZyEntry $=1 \&$ SeekPage $=x \& Z y P U R L$.

FAO/WHO. 1997. Risk management and food safety. Report of a Joint FAO/WHO Consultation Rome, Italy, 27 to 31 January 1997. Accessed Mar. 9, 2015. http://www.fao.org/3/a-w4982e.pdf.

FDA (US Food and Drug Administration). 2010. Morningland Dairy Conducting Nationwide Voluntary Recall of All Cheese Labeled as Morningland Dairy and Ozark Hills Farm because of possible health risk. Accessed Mar. 9, 2015. http://www.fda.gov/Safety/ Recalls/ucm224494.htm.
Franz, E., S. O. Tromp, H. Rijgersberg, and H. J. Van Der Fels-Klerx. 2010. Quantitative microbial risk assessment for Escherichia coli O157:H7, Salmonella, and Listeria monocytogenes in leafy green vegetables consumed at salad bars. J. Food Prot. 73:274-285.

Jablonski, L. M., and G. A. Bohach. 2001. Staphylococcus aureus. Pages 410-434 in Fundamentals of Food Microbiology. L. Beuchat, M. Doyle, and T. Montville, ed. American Society for Microbiology, Washington DC.

Jørgensen, H. J., T. Mathisen, A. Lovseth, K. Omoe, K. S. Qvale, and S. Loncarevic. 2005. An outbreak of staphylococcal food poisoning caused by enterotoxin $\mathrm{H}$ in mashed potato made with raw milk. FEMS Microbiol. Lett. 252:267-272.

Jung, H. 2011. Consumer survey and hazard analysis for the improvement of food hygiene and safety in purchase. Dissertation for Degree of Master, Korea University.

Latorre, A. A., A. K. Pradhan, J. A. Van Kessel, J. S. Karns, K. J. Boor, D. H. Rice, K. J. Mangione, Y. T. Gröhn, and Y. H. Schukken. 2011. Quantitative risk assessment of listeriosis due to consumption of raw milk. J. Food Prot. 74:1268-1281.

Le Loir, Y., F. Baron, and M. Gautier. 2003. Staphylococcus aureus and food poisoning. Genet. Mol. Res. 2:63-76.

Lee, Y.-S., J.-H. Ha, K.-H. Park, S.-Y. Lee, Y.-J. Choi, D.-H. Lee, S.-H. Park, E.-S. Moon, K. Ryu, H.-S. Shin, and S.-D. Ha. 2008. Survey on storage temperature of domestic major chilled foods in refrigerator. J. Food Hyg. Safety 23:304-308.

MFDS (Ministry of Food and Drug Safety). 2013. Quantitative standard establishment and risk assessment of foodborne pathogens on cheese. Accessed Mar. 09, 2015. http://img.kisti. re.kr/originalView/originalView.jsp

MFDS (Ministry of Food and Drug Safety). 2014a. Food code. Glossary. Accessed Dec. 30, 2014. http://fse.foodnara.go.kr/residue/ $\mathrm{RS} / \mathrm{jsp} / \mathrm{menu}$-02_01_03.jsp?idx=3.

MFDS (Ministry of Food and Drug Safety). 2014b. Status of food poisoning outbreaks in Korea. Accessed Mar. 09, 2015. http://www. mfds.go.kr/e-stat/index.do.

MFDS (Ministry of Food and Drug Safety). 2014c. Standard for livestock product processing ingredients. pp. 42-45.

NFSI (National Food Safety Initiative). 1997. Food Safety from Farm to Table: A report to the President. U.S. Environmental Protection Agency, U.S. Department of Health and Human Services, and the U.S. Department of Agriculture, Washington, DC.

NPR (National Public Radio). 2010. An oops on the Costco Freebie menu: Gouda cheese with E. coli. Accessed Mar. 09, 2015. http:// www.npr.org/blogs/health/2010/11/05/131096497/an-oops-onthe-costco-freebie-menu-gouda-cheese-with-e-coli

Ratkowsky, D. A., J. Olley, T. A. McMeekin, and A. Ball. 1982. Relationship between temperature and growth rate of bacterial cultures. J. Bacteriol. 149:1-5.

Rose, J. B., and C. N. Haas. 1999. A risk assessment framework for the evaluation of skin infections and the potential impact of antibacterial soap washing. Am. J. Infect. Control 27:S26-S33.

Schmitt, M., U. Schuler-Schmid, and W. Scmidt-Lorenz. 1990. Temperature limits of growth, TNase, and enterotoxin production of Staphylococcus aureus strains isolated from foods. Int. J. Food Microbiol. 11:1-19.

Tamarapu, S., J. L. McKillip, and M. Drake. 2001. Development of a multiplex polymerase chain reaction assay for detection and differentiation of Staphylococcus aureus in dairy products. J. Food Prot. 64:664-668.

Vose, D. J. 1998. The application of quantitative risk assessment to microbial food safety. J. Food Prot. 61:640-648.

Wisconsin Cheese. 2014. Cheese statistics. Accessed Dec. 31, 2014. http://media.eatwisconsincheese.com/dairyimpact/statistics/ cheesestatistics. 